\title{
Caracterização da resistência para acaricidas no carrapato Boophilus microplus*
}

\author{
Characterization of acaricide resistance in Boophilus microplus

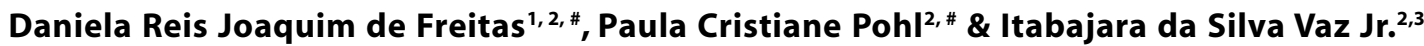

\begin{abstract}
RESUMO
Boophilus microplus é um ectoparasita hematófago de bovinos, presente em áreas tropicais e subtropicais no mundo. É causador de enormes perdas econômicas pela espoliação que causa ao hospedeiro, além de ser transmissor de Anaplasma sp. e Babesia spp. O principal método de controle utilizado atualmente é o controle químico, que, embora eficiente, é caro, causa danos ao meio ambiente e deixa resíduos na carne. Além disso, é crescente o número de relatos que apontam um aumento das populações resistentes de carrapatos a diversos princípios químicos presentes nos acaricidas. As bases moleculares da resistência em Boophilus microplus ainda não são claramente conhecidas, mas muitos estudos indicam alguns dos mecanismos. Diferentes grupos de enzimas presentes em diferentes rotas metabólicas compõem os mecanismos de resistência e detoxificação celular, além de uma série de mutações que podem aumentar a tolerância a um determinado composto químico. Neste momento, outros tipos de controle, como o biológico e o imunológico estão sendo trabalhados para evitar a resistência nas populações de carrapato. No entanto, o controle biológico ainda não é viável para grandes rebanhos e a proteção induzida por vacinas não é suficiente para permitir o controle do B. microplus. O estudo dos mecanismos de resistência no carrapato pode ser de fundamental importância para seu controle em rebanhos.
\end{abstract}

Descritores: Boophilus microplus, resistência, mecanismos moleculares.

\section{ABSTRACT}

The tick Boophilus microplus is a hematophagous ectoparasite of bovine, present in tropical and subtropical areas in the world. It is responsible for great economic losses for the host expoliation, moreover it transmittes Anaplasma sp. and $B a$ besia spp. The most important method for the control of the cattle tick used actually is the chemical control, that it is efficient but dispendious, causes damage to enviroment and contaminates the food. In addition, the number of relates increases and shows the increase in tick resistant populations to several chemical principles present in the acaricides. The molecular basis of resistance in Boophilus microplus are not known, but several studies shows the most mechanisms. Different group of enzymes in different metabolic pathways form the cellular resistance mechanisms and detoxification, moreover several mutations can increase the tolerance to a chemical coumpound. In this moment, other types of control, such as biological and immunological controls has been developed for decrease the resistance in tick populations. But the biological control yet is not viable for large cattle breedings and the protection induced by vaccination is not sufficient to control of B. microplus. The study of resistance mechanisms in the tick could be fundamental importance for its control.

Key words: Boophilus microplus, resistance, molecular mechanisms. 


\section{INTRODUÇÃO}

\section{CONTROLES Biológico E IMUNOLÓGico}

\section{USO DE ACARICIDAS E AS BASES MOLECULARES DA RESISTÊNCIA}

\section{Bases moleculares da resistência}

\section{Citocromos P450}

\section{Esterases}

4. Glutationa S-transferases

\section{Outros Alvos}

\section{DETECÇÃO DA RESISTÊNCIA}

\section{ConCluSÃo}

\section{INTRODUÇÃO}

O carrapato Boophilus microplus é um ectoparasita hematófago de bovinos presente nas regiões tropicais e subtropicais do mundo [43], e representa um dos principais problemas econômicos para criadores de gado, pois os prejuízos econômicos vão desde grandes perdas na produção de leite e carne [80] e danos no couro causados por reações inflamatórias nos locais de fixação do carrapato [81] a transmissão de doenças das quais o carrapato é vetor, como a tristeza parasitária bovina (causada por protozoários do gênero Babesia e pela rickétsia do gênero Anaplasma) [57,87] e prejuízos relacionados à mão-de-obra, despesas com instalações, compra dos carrapaticidas e de equipamentos de suporte para aplicação dos mesmos nos rebanhos [10]. Jonsson et al. [44,45] mostraram que na Austrália, o custo total para a criação de gado (excluindo custos associados com a febre do carrapato) baseada nas práticas de manejo de 1998 é de quatro milhões e noventa e seis mil dólares por ano, sendo que $49 \%$ deste custo está relacionado aos custos do controle e $51 \%$ as perdas na produção. Por isto, a necessidade de métodos de controle adequados e mais baratos é cada vez maior. Dois métodos que têm sido muito estudados nas últimas décadas são os controles biológico e imunológico [2,3,15-17,32].

\section{CONTROLES Biológico E IMUNOLóGico}

O controle biológico é baseado em diferentes princípios, que vão desde rodízio de pastagens e/ou cultivo de pastagens que dificultam a sobrevivência das fases de vida livre do carrapato [26,79], seleção de raças menos sensíveis ao carrapato, utilização de predadores naturais (como a garça vaqueira Egretta ibis [2] e formigas carnívoras [33]), ou ainda a utilização de espécies parasitas, como bactérias (Escherichia coli, Cedecea lapagei e Enterobacter agglomerans [8], já normalmente encontradas no aparelho reprodutor feminino do carrapato) ou fungos (como o fungo entomo-patogênico Metarhizium anisopliae, muito estudado nos últimos anos em diferentes espécies de carrapato $[15,32,46,89])$. Nematódeos, que têm se mostrado eficientes no controle biológico de insetos [72] também têm sido estudados como ferramentas de controle de carrapatos [20].

Um outro método de controle com efetivo sucesso é o uso de compostos naturais atuando como pesticidas. Em diferentes espécies de insetos, "spinosad", um pesticida natural composto pela combinação de duas lactonas macrocíclicas (A e D) obtidas de produtos de fermentação isoladas do fungo Saccharopo-lyspora spinosa $[6,41,53,64]$ tem mostrado excelentes resultados. Davey et al. [20] testaram em bovinos diferentes concentrações de "spinosad" e obtiveram uma queda drástica no número de fêmeas ingurgitadas, na massa de ovos e no índice de fecundidade. Em 2000, Guglielmone et al. [35] mostraram que em bovinos banhados em moxidectina, outra lactona macrocíclica usada como endectocida, havia um controle de quase $95 \%$ na infestação de carrapatos. Posteriormente, em 2003, Aguilar-Tipacamu e RodriguezVivaz constataram um controle acima de $95 \%$ em fêmeas adultas ingurgitadas entre 7 e 28 dias após o tratamento dos bovinos com moxidectina e $74,9 \%$ no dia 35 após o tratamento. Quando usado com amitraz 
o controle chegou a quase $100 \%$ [1]. Atualmente, é possível utilizar moxidectina juntamente com acaricidas [35].

O controle imunológico tem sido muito estudado nas últimas cinco décadas. Diversos grupos no mundo todo têm se dedicado ao desenvolvimento de uma vacina contra $B$. microplus. O uso de novas metodologias de biologia molecular e imunologia tem auxiliado na identificação de novos antígenos que possam gerar uma resposta imune protetora, na produção de anticorpos monoclonais, que têm sido uma ferramenta útil na caracterização de antígenos envolvidos na resposta protetora contra parasitas [47], bem como propiciado um maior conhecimento dos mecanismos de resposta imunológica do animal a ser imunizado.

Um marco no desenvolvimento de vacinas contra B. microplus foi a identificação de uma proteína de intestino, nomeada Bm86, base de duas vacinas comerciais presentes no mercado: a TickGard, de origem australiana e produzida em E. coli e a Gavac, de origem cubana e produzida em Pichia pastoris. Embora disponíveis no mercado, estas vacinas não asseguram um grau de proteção suficiente para serem utilizadas sem o uso concomitante de acaricidas $[44,86]$. Outros antígenos têm sido associados a Bm86 para aumentar a eficiência da resposta imune em bovinos $[68,86]$.

Além dos antígenos que compõem as vacinas comercialmente disponíveis descritas acima, outras proteínas que também conferem algum grau de imunoproteção ou induzem a produção de anticorpos que interferem no sucesso reprodutivo do carrapato têm sido descritas, como o caso da glicoproteína BYC (Boophilus Yolk Cathepsin) [18,53], inibidores de tripsina (BmTIs) [3], e vitelina [82]. Moléculas envolvidas em diferentes funções fisiológicas do carrapato e na sua interação com o hospedeiro também têm sido caracterizadas por diversos grupos de pesquisa, como a THAP (Tick Heme-binding Aspartic proteinase) [76], a glutationa S-transferase (GST) [19,37, 69], a VTDCE [75], a BmCL1 [66,67], a calreticulina (CRT) [28,58], a paramiosina (BmPRM) [27,54] e a BooKase $[4,40]$.

Portanto, embora os controles biológico e imunológico sejam hoje interessantes por uma questão econômica e ambiental, ainda não são totalmente efetivos, exigindo a utilização de produtos químicos para maior estabilidade operacional [64]. Por isto, é importante entender os mecanismos que permitem aos carrapatos desenvolverem resistência aos diferentes princípios químicos presentes nos acaricidas.

\section{USO DE ACARICIDAS E AS BASES MOLECULARES DA RESISTÊNCIA}

O mais eficaz método de controle para populações de carrapato foi (e é) o uso de acaricidas. O controle com acaricidas teve início nos anos 50 [64], mas na realidade, as propriedades inseticidas do DDT já eram conhecidas desde a década de 30 . Seu uso massivo como pesticida, porém, começou nos anos 50. Apesar de ainda hoje o controle químico ser o único método eficaz, já que os controles imunológico e biológico ainda possuem apenas uma função complementar, é também dispendioso, devido o alto custo com a aquisição dos produtos químicos, instalações adequadas e com a mão-de-obra para a aplicação dos produtos. A contaminação com resíduos químicos da carne e do leite e a contaminação do ambiente, através do solo e dos rios têm sido atualmente uma das maiores preocupações quanto a seu uso $[60,64]$. Uma das maneiras de diminuir o problema da contaminação seria a utilização de biodegradação de compostos xenobióticos, método que vem sendo pesquisado há pelo menos duas décadas [88].

Ainda que seja resolvido o problema da contaminação ambiental, um outro problema ainda persiste com o uso de acaricidas: a seleção de populações de carrapato resistentes aos diferentes princípios químicos utilizados [13]. Isto gera um ciclo vicioso: por estar sendo selecionadas populações resistentes a determinados princípios ativos, há uma necessidade de utilizar seqüencialmente acaricidas com diferentes composições; e o uso destes acaricidas com diferentes composições muitas vezes em um curto período de tempo ou concomitantemente acaba por selecionar populações mais resistentes ou resistentes a mais de um princípio ativo. Deve-se destacar que foi mostrado que o B. microplus pode apresentar resistência mais rapidamente que outros carrapatos, provavelmente, pelo menor período de tempo entre as gerações [49].

Como ao longo destas últimas cinco décadas têm-se utilizado acaricidas baseados em diferentes princípios químicos [36] (arsenicais, organoclorados, organofosforados, carbamatos, nitroguanidinas, fenilpirazoles, formamidinas, piretróides, avermectinas, lactonas macrocíclicas e fenil uréias) diversos mecanismos de resistência foram sendo desenvolvidos como estratégia de sobrevivência pelo carrapato. A maior 
parte das populações de $B$. microplus no mundo é resistente a organofosforados [12] e piretróides. Mas como ocorre esta resistência? Que mecanismos são estes?

\section{Bases moleculares da resistência}

A base molecular da resistência tem sido estudada em diferentes espécies de artrópodes, principalmente em insetos, mas algo já é conhecido em carrapatos. Artrópodes em geral possuem um curto período de tempo entre uma geração e outra. Isto favorece o surgimento de populações com diferentes características genéticas, de acordo com a pressão seletiva que estão sofrendo. Estas características variam desde a redução do poder de penetração do pesticida, aumento do poder seqüestrante de moléculas tóxicas ou mesmo insensibilidade a compostos tóxicos [61] a aumento da detoxificação celular $[9,61,65]$, o que torna os pesticidas utilizados defasados em um curto espaço de tempo e torna necessário o aumento da concentração de uso, mudança de princípio ativo ou a utilização de outros princípios ativos combinados [80]. As bases moleculares da resistência podem ser resumidas em 3 tipos: aumento de expressão de genes ou aumento da atividade de enzimas envolvidas em metabolismo de xenobióticos/detoxificadoras; mutações em neurorreceptores e mutações em canais de sódio [55,61,70]. Três famílias de proteínas são as principais responsáveis pelo metabolismo de inseticidas: os citocromos P450, as esterases (Est) e as glutationa S-transferases (GSTs) [65]. As proteínas destas famílias também estão envolvidas na síntese e na quebra de vários metabólitos endógenos, na proteção contra o estresse oxidativo, na transmissão de sinais nervosos e no transporte celular [38].

\section{Citocromos P450}

Os citocromos P450 são uma superfamília ubíqua de enzimas que catalisam uma grande variedade de reações químicas e agem sobre diferentes substratos [30,38]. Estão envolvidas no metabolismo de compostos endógenos como esteróides, ácidos graxos e colesterol, e de compostos exógenos como drogas e pesticidas [22,55]. Simplificando, P450 liga-se a compostos tóxicos oxidando-os, tornando-os mais solúveis e, portanto, mais fáceis de excretar [38]. P450 monoxigenases são responsáveis pela detoxificação de piretróides e organofosforados em artrópodes, inclusive em B. microplus [50]. Em Drosophila foi verificada que a superexpressão de dois genes $\mathrm{P} 450$ genes,
Cyp6g1 e Cyp12d1 são responsáveis pela sua resistência a DDT, um organoclorado [29].

\section{Esterases}

As esterases estão envolvidas na detoxificação de organofosforados, em especial as fosfotriesterases (PTEs), acetilcolinesterases (AChE) e as carboxilesterases. Os organofosforados inibem esterases por fosforilação no sistema nervoso. Algumas moléculas de esterase, no entanto, são hábeis em remover, sem aparente efeito tóxico, moléculas de organofosforado [77,78]. A bem conhecida síndrome colinérgica é causada por forte inibição de $\mathrm{AChE}$, que interrompe os estímulos colinérgicos. Mutações no sítio ativo da acetilcolinesterase e a superexpressão de genes de esterases para organofosforados e carbamatos têm sido recentemente relatados, principalmente em moscas domésticas [65] e em outras espécies [9]. Existe, ainda, correlação de atividade e expressão de genes de esterases com a resistência a piretróides [21].

\section{Glutationa S-transferases}

Para completar o quadro das principais enzimas envolvidas na metabolização de pesticidas, as glutationa S-transferases (GSTs) são uma família multifuncional de enzimas presentes ubiquamente em organismos aeróbicos e entre suas funções pode-se destacar transporte intracelular, participação em processos digestivos, sínte-se de prostaglandinas e, principalmente, detoxificação de substâncias tóxicas e proteção contra stress oxidativo [50,69]. O mecanismo de ação das GSTs é, basicamente, ligar-se a grupamentos eletrofílicos e conjugá-los a uma molécula de glutationa reduzida, que ao ligar-se a tal grupamento eletrofílico, passará do estado reduzido para o estado oxidado, e formará um composto mais solúvel e mais fácil de ser excretado [25].

Altos níveis de expressão de GST tem sido relacionado à resistência a inseticidas em vários organismos [70], além de estar associada a reações alérgicas mediadas por IgE [62]. Em B. microplus a GST foi isolada de larvas [37] e de glândula salivar [69]. Da Silva Vaz Jr. et al. em 2004 demonstraram in vitro o efeito de diferentes acaricidas sobre a atividade de uma GST [19]. Entretanto, ainda não foram demonstradas evidências correlacionando a expressão de GST a resistência frente aos acaricidas. Em outros artrópodes, já foi verificado um aumento de expressão e/ ou de atividade de GSTs [25,69,70], que agem princi- 
palmente sobre organoclorados como DDT e organofosforados, estes últimos por duas vias distintas: Odealquilação ou O-dearilação [85]. Embora não se tenha ainda dados concretos sobre o papel das GSTs na resistência a piretróides, alguns autores apontam para um papel de seqüestro das moléculas de inseticida ou de metabolização de produtos de peroxidação de lipídios causados por inseticidas [84].

\section{Outros Alvos}

A resistência a inseticidas também pode advir de mudanças na sequiência ou na conformação de proteínas que normalmente se ligariam a estes compostos [38]. A resistência a ciclodienos está relacionada a mutações de um receptor do neurotransmissor GABA [70]. Mutações em genes de canal de sódio também são responsáveis por resistência a DDT e piretróides [61,65, 70], pois causam alterações nos canais de sódio causam redução na sensibilidade do sistema nervoso central aos princípios ativos [56]. Já foram identificadas mutações em receptores de receptores de octopamina, o que causa resistência a amitraz, uma das formamidinas mais utilizadas hoje [81].

Novos acaricidas estão sendo testados no mercado, entre eles as lactonas macrocíclicas, que agem como bloqueadores da estimulação neural [81], e os inibidores de desenvolvimento de carrapato flurazuron e fipronil. Como são relativamente novos no mercado, nenhum caso de resistência relevante ainda foi detectado [71].

\section{DETECÇÃO DA RESISTÊNCIA}

Pode-se determinar de uma maneira bastante refinada a resistência em carrapatos, através de dife- rentes testes biológicos a campo ou em laboratório. Um dos testes baseia-se na utilização do carrapaticida em diferentes concentrações e no índice de sobrevivência de larvas expostas a estas concentrações. Este teste é conhecido como o teste do pacote ("Larval Packet Test" - LPT) [51]. Guerrero et al. [34] através da técnica de PCR conseguiu identificar mutações em linhagens mexicanas de B. microplus que ocorrem por substituição de dois aminoácidos em uma proteína de canal de sódio. Essas mutações, com as substituições de Phe para Ile e Asp para Asn são responsáveis por conferir a estas linhagens de carrapato resistência a piretróides.

Através de PCR, é possível detectar uma mutação específica em genes de canal de sódio associada com resistência a permetrina utilizando um único carrapato em qualquer estágio de desenvolvimento e em poucas horas. Também por PCR, é possível detectar um gene esterase responsável pela metabolização de permetrina, CzEst9 [31]. Outros métodos também têm sido desenvolvidos para detectar rapidamente resistência, baseados em ensaios utilizando DNA ou ELISA para genotipagem de carrapatos a fim de obter um perfil de susceptibilidade a vários pesticidas [31].

\section{Conclusão}

Para concluir, pode-se salientar que através de uma maior compreensão dos mecanismos moleculares da resistência é que poderá criar, no futuro, novos métodos de manejo que permitam prolongar a vida útil dos princípios ativos em uso, além de desenvolver drogas menos sensíveis ao desenvolvimento de resistência pelos carrapatos.

\section{REFERÊNCIAS}

1 Aguilar-Tipacamu G. \& Rodriguez-Vivas R.I. 2003. Effect of moxidectin against natural infestation of the cattle tick Boophilus microplus (Acarina: Ixodidae) in the Mexican tropics. Veterinary Parasitology. 111: 211-216.

2 Alves-Branco F.P., Echevarria F.A.M. \& Siqueira A.S. 1983. Garça vaqueira Egretta ibis e o controle biológico do carrapato Boophilus microplus. Comunicado Técnico da EMBRAPA. 1: 1-4.

3 Andreotti R., Gomes A., Malavazi-Piza K.C., Sasaki S.D., Sampaio C.A. \& Tanaka A.S. 2002. BmTI antigens induce a bovine protective immune response against Boophilus microplus tick. International Immunopharmacology. 2: 557-563.

4 Bastiani M., Hillebrand S., Horn F., Kist T.B., Guimarães J.A. \& Termignoni C. 2002. Cattle tick Boophilus microplus salivary gland contains a thiol-activated metalloendopeptidase displaying kininase activity. Insect Biochemical and Molecular Biology. 32: 1439-1446.

5 Baxter G.D. \& Barker S.C. 2002. Analysis of the sequence and expression of a second putative acetylcholinesterase cDNA from organophosphate-susceptible and organophosphate-resistant cattle ticks. Insect Biochemical and Molecular Biology. 32: 815-820. 
6 Bond J.G., Marina C.F. \& Williams T. 2004. The naturally derived insecticide spinosad is highly toxic to Aedes and Anopheles mosquito larvae. Medical Veterinary Entomology. 1: 50-56.

7 Braz G.R., Moreira M.F., Masuda H. \& Oliveira P.L. 2002. Rhodnius heme-binding protein (RHBP) is a heme source for embryonic development in the blood-sucking bug Rhodnius prolixus (Hemiptera, Reduviidae). Insect Biochemical and Molecular Biology. 32: 361-367.

8 Brum J.G.W. 1988. Infecção em teleóginas de Boophilus microplus (Acari: Ixodidae) por Cedecea lapagei Grimont $e t$ al., 1981: etiopatogenia e sazonalidade. 200f. Tese (Doutor em Ciências). Instituto de Biologia. Universidade Federal Rural do Rio de Janeiro, R.J.

9 Casida J.E. \& Quistad G.B. 1998. Golden age of insecticide: Past, Present, or Future? Annual Review of Entomology. 43 : 1-16.

10 Cordovés C.O. 1999. Carrapato: controle e erradicação. Alegrete: Gralha, 130p.

11 Cossio-Bayugar R., Barhoumi R., Burghardt R.C., Wagner G.G. \& Holman P.J. 2002. Basal cellular alterations of esterase, glutathione, glutathione S-transferase, intracellular calcium and membrane potenctials in coumaphos-resistant Boophilus microplus (Acari: Ixodidae) cell lines. Pesticide Biochemistry and Physiology. 72: 1-9.

12 Cossio-Bayugar R., Wagner G.G. \& Holman P.J. 2002. In vitro generation of organophosphate resistant Boophilus microplus (Acari: Ixodidae) cell lines. Journal of Medical Entomology. 39: 278-284.

13 Crampton A. L., Baxter G.D. \& Barker S.C. 1999. .Identification and characterisation of a cytochrome P450 gene and processed pseudogene from an arachnid: the cattle tick, Boophilus microplus. Insect Biochemical and Molecular Biology. 29: 377-384.

14 Crampton A.L., Miller C., Baxter G.D. \& Barker S.C. 1998. Expressed sequenced tags and news genes from the cattle tick, Boophilus microplus. Experimental and Applied Acarology. 22: 177-186.

15 Da Costa G.L., Sarquis M.I., De Moraes A.M. \& Bittencourt V.R. 2002. Isolation of Beauveria bassiana and Metarhizium anisopliae var. anisopliae from Boophilus microplus tick (Canestrini, 1887), in Rio de Janeiro State, Brazil. Mycopathologia. 154: 207-209.

16 Da Silva Vaz Jr. I., Ozaki S.L. \& Masuda A. 1994. Serum of Boophilus microplus infested cattle reacts with different tick tissues. Veterinary Parasitology. 52: 71-78.

17 Da Silva Vaz Jr. I., Martinez R.H.M., Oliveira A.T.D., Heck A., Logullo C., Gonzales J.C., Dewes H. \& MasudaA. 1996. Functional bovine immunoglobulins in Boophilus microplus hemolymph. Veterinary Parasitology. 62: 155-160.

18 Da Silva Vaz Jr. I., Logullo C.J., Sorgine M., Velloso F.F., Gonzales J.C., Masuda H., Oliveira P.L. \& Masuda A. 1998. Immunization of bovines with a new protein isolated from egg of Boophilus microplus. Veterinary Immunology and Immu-nopathology. 66: 331-341.

19 Da Silva Vaz Jr. I, Torino Lermen T., Michelon A., Sanchez Ferreira C.A., Joaquim de Freitas D.R., Termignoni C. \& Masuda A. 2004. Effect of acaricides on the activity of a Boophilus microplus glutathione S-transferase. Veterinary Para-sitology. 119: 237-245.

20 Davey R.B., George J.E. \& Snyder D.E. 2001. Efficacy of a single whole-body spray treatment of spinosad, against Boophilus microplus (Acari: Ixodidae) on cattle. Veterinary Parasitology. 99: 41-52.

21 Dejersey J., Nolan J., Dave P.A. \& Riccles P.W. 1985. Separation and characterization of the pyrethroid-hydrolyzing esterases of cattle tick Boophilus microplus. Pesticide Biochemistry and Physiology. 23: 349-357.

22 Denholm I., Devine G.J. \& Williamson M.S. 2002. Evolutionary genetics. Insecticide resistance on the move. Science. 297: 2222-2223.

23 De Oliveira Vasconcelos V., Furlong J., de Freitas G.M., Dolinski C., Aguillera M.M., Rodrigues R.C. \& Prata M. 2004. Steinernema glaseri Santa Rosa strain (Rhabditida: Steinernematidae) and Heterorhabditis bacteriophora CCA Strain (Rhabditida: Heterorhabditidae) as biological control agents of Boophilus microplus (Acari: Ixodidae). Parasitology Research. 94: 201-206.

24 Drummond R.O., Ernst S.E., Trevino J.L., Gladney W.J. \& Graham O.H. 1976. Tests of acaricides for control of Boophilus annulatus and B. microplus. Journal of Economic Entomology. 69: 37-40.

25 Enayati A.A., Ranson H. \& Hemingway J. 2005. Insect glutathione transferases and insecticide resistance. Insect Molecular Biology. 1: 3-8.

26 Farias N.A.R., Gonzales J.C. \& Saibro J.C. 1986. Antibiose e antixenose entre forrageiras em larvas de carrapato do boi. Pesquisa Agropecuária Brasileira. 21: 1313-1320.

27 Ferreira C.A., Barbosa M.C., Silveira T.C., Valenzuela J.G., Da Silva Vaz Jr. I. \& Masuda A. 2002. cDNA cloning, expression and characterization of a Boophilus microplus paramyosin. Parasitology. 125: 265-274. 
28 Ferreira C.A., Da Silva Vaz Jr. I., Da Silva S.S., Haag K.L., Valenzuela J.G. \& Masuda A. 2002. Cloning and partial characterization of a Boophilus microplus (Acari: Ixodidae) calreticulin. Experimental Parasitology. 101: 25-34.

29 Festucci-Buselli R.A., Carvalho-Dias A.S., De Oliveira-Andrade M., Caixeta-Nunes C., Li H.M., Stuart J.J., Muir W., Scharf M.E. \& Pittendrigh B.R. 2005. Expression of Cyp6g1 and Cyp12d1 in DDT resistant and susceptible strains of Drosophila melanogaster. Insect Molecular Biology. 1: 69-77.

30 Feyereisen R., Koener J.F., Farnsworth D.E. \& Nebert D.W. 1989. Isolation and sequence of cDNA encoding a cytochrome P-450 from an insecticide-resistant strain of the house fly, Musca domestica. Proceedings of the National Academy of Science of the United States of America. 86: 1465-1469.

31 Foil L.D., Coleman P., Eisler M., Fragoso-Sanchez H., Garcia-Vazquez Z., Guerrero F.D., Jonsson N.N., Langstaff I.G., Li A. Y., Machila N., Miller R. J., Morton J., Pruett J.H. \& Torr S. 2004. Factors that influence the prevalence of acaricide resistance and tick-borne diseases. Veterinary Parasitology. 125: 163-181.

32 Frazzon A.P., Da Silva Vaz Jr. I., Masuda A., Schrank A. \& Vainstein M.H. 2000. In vitro assessment of Metarhizium anisopliae isolates to control the cattle tick Boophilus microplus. Veterinary Parasitology. 94: 117-125.

33 Gonzales J.C. 1975. O controle do carrapato bovino. Porto Alegre: Sulina, 104p.

34 Guerrero F.D., Li A.Y. \& Hernandez R. 2002. Molecular diagnosis of pyrethroid resistance in Mexican strains of Boophilus microplus (Acari: Ixodidae). Journal of Medical Entomology. 39: 770-776.

35 Guglielmone A.A., Mangold A.J., Munoz Cobenas M.E., Scherling N., Garcia Posse F., Anziani O.S. \& Ioppolo M. 2000. Moxidectin pour-on for control of natural populations of the cattle tick Boophilus microplus (Acarina: Ixodidae). Veterinary Parasitology. 87: 237-241.

36 Häuserman W., Friedel T., Hess E.A. \& Strong M.B. 1992. A new active ingredient for a new approach to protect cattle against ticks In: Proceedings of XIX International Congress of Entomology (Beijing, China). p.138.

37 He H., Chen A.C., Davey R.B., Ivie G.W. \& George J.E. 1999. Characterization and molecular cloning of glutathione S-transferase gene from the tick, Boophilus microplus (Acari: Ixodidae). Insect and Biochemistry and Molecular Biology. 29: 737-743.

38 Hemingway J., Field L. \& Vontas J. 2002. An overview of insecticide resistance. Science. 298: 96-97

39 Hernandez R., Guerrero F.D., George J.E. \& Wagner G.G. 2002. Allele frequency and gene expression of a putative carboxylesterase-encoding gene in a pyrethroid resistant strain of the tick Boophilus microplus. Insect Biochemistry and Molecular Biology. 32: 1009-1016.

40 Horn F., dos Santos P.C. \& Termignoni C. 2000. Boophilus microplus anticoagulant protein: an antithrombin inhibitor isolated from the cattle tick saliva. Archives of Biochemistry and Biophysics. 384: 68-73.

41 Huang F., Subramanyam B. \& Toews M.D. 2004. Susceptibility of laboratory and field strains of four stored-product insect species to spinosad. Journal of Economic Entomology. 6: 2154-2159.

42 Jaworski D.C., Simmen F.A., Lamoreaux W., Coons L.B., Muller M.T. \& Needham G.R. 1995. A secreted calreticulin protein in ixodid tick (Amblyomma americanum) saliva. Journal Insect Physiology. 41: 369-375.

43 Johnston L.A.Y., Kemp D.H. \& Pearson R.D. 1986. Immunization of cattle against Boophilus microplus using extracts derived from adult female ticks: Effects of induced immunity on tick populations. International Journal for Parasitology. 16: $27-34$.

44 Jonsson N.N., Mayer D.G. \& Green P.E. 2000. Possible risk factors on Queensland dairy farms for acaricide resistance in cattle tick (Boophilus microplus). Veterinary Parasitology. 88: 79-92.

45 Jonsson N.N., Davis R. \& De Witt M. 2001. An estimate of the economic effects of cattle tick (Boophilus microplus) infestation on Queensland dairy farms. Austalian Veterinary Journal. 79: 826-831.

46 Kaaya G. P., Mwangi E. N. \& Ouna E.A. 1996. Prospects for biological control of livestock ticks, Rhipicephalus appendiculatus and Amblyomma variegatum, using the entomogenous fungi Beauveria bassiana and Metarhizium anisopliae. Journal of Invertebrate Pathology. 67: 15-20.

47 Kelly E.A.B. \& Colley D.G. 1988. In vivo effects of monoclonal anti-13t4 antibody on immune responsiveness of mice infected with Schistosoma-mansoni - reduction of irradiated cercariae-induced resistance. Journal of Immunology. 140: 2737-2745.

48 Kemp D.H., Gale K.R., Nari A. \& Sabatini G.A. 1998. Acaricide resistance in the cattle-ticks Boophilus microplus and B. decoloratus: review of resistance data; standartization of resistance tests and recommendations for the intergrated parasite control to delay resistance. Report to the animal health services, AGAH. Rome, FAO. 37 pp. 
49 Kocan K.M. 1995. Targeting ticks for control of selected haemoparasitic diseases of cattle. Veterinary Parasitology. 57: $121-151$.

50 Lee A.J., Huntley J., Van den Broek A., Coates D. \& Isaac R.E. 2002. Expression and characterisation of a Psoroptes ovis glutathione S-transferase. Veterinary Parasitology. 105: 49-63.

51 Li A.Y., Davey R.B., Miller R.J. \& George J.E. 2003. Resistance to coumaphos and diazinon in Boophilus microplus (Acari: Ixodidae) and evidence for the involvement of an oxidative detoxification mechanism. Journal of Medical Entomology. 4: 482-490.

52 Liu S. \& Li Q.X. 2004. Photolysis of spinosyns in seawater, stream water and various aqueous solutions. Chemosphere. 11: 1121-1127.

53 Logullo C., Da Silva Vaz Jr. I., Sorgine M.H.F., Paiva-Silva G.O., Faria F.S., Zingali R., Rosa de Lima M., Abreu L., Oliveira E.F., Alves E.W., Masuda H., Gonzales J.C., Masuda A. \& Oliveira P.L. 1998. Isolation of an aspartic proteinase precursor from the egg of a hard tick, Boophilus microplus. Parasitology. 116: 525-532.

54 Maroto M., Arredondo J.J., San Roman M., Marco R. \& Cervera M. 1995. Analysis of the paramyosin/miniparamyosin gene. The Journal of Biological Chemistry. 270: 4375-4382.

55 Martin T., Ochou O.G., Vaissayre M. \& Fournier D. 2003. Oxidases responsible for resistance to pyrethroids sensitize Helicoverpa armigera (Hubner) to triazophos in West Africa. Insect Biochemistry and Molecular Biology. 9: 883-887.

56 Martinez-Torres D., Chandre F., Williamson M.S., Darriet F., Bergé J.B., Devonshire A. L., Guillet P., Pasteur N. \& Pauron D. 1998. Molecular characterization of pyrethroid knockdown resistance $(k d r)$ in the major malaria vector Anopheles gambiae. Insect Molecular Biology. 7: 189-184.

57 McCosker P.L. 1975. Control of piroplasmosis and anaplasmosis in cattle. A practical manual. Rome, FAO. 64 pp.

58 Michalak M., Milner R.E., Burns K. \& Opas M. 1992. Calreticulin. Biochemical Journal. 285: 681-692.

59 Miller R.J., Davey R.B. \& George J.E. 2002. Modification of the food and agriculture organization larval packet test to measure amitraz-susceptibility against ixodidae. Journal of Medical Entomology. 39: 645-651.

60 Nolan J. 1985. Mechanisms of resistance to chemicals in arthropod parasites of veterinary importance. Veterinary Parasitology. 18: 155-166.

61 Oakeshott J.G., Home I., Sutherland T.D. \& Russell R.J. 2003. The genomics of insecticide resistance. Genome Biology. 4: 202.

62 O’Neill G.M., Donovan G.R. \& Baldo B.A. 1994. Cloning and characterization of a major allergen of the house dust mite, Dermatophagoides pteronyssinus, homologous with glutathione S-transferase. Biochimica et Biophysica Acta. 1219: 521-528.

63 Pineda S., Budia F., Schneider M. I., Gobbi A., Vinuela E., Valle J. \& Del Estal P. 2004. Effects of two biorational insecticides, spinosad and methoxyfenozide, on Spodoptera littoralis (Lepidoptera: Noctuidae) under laboratory conditions. Journal of Economic Entomology. 6: 1906-1911.

64 Pruett J.H. 1999. Immunological control of arthropods ectoparasites - a review. International Journal for Parasitology. 29: 25-32.

65 Ranson H., Claudianos C., Ortelli F., Abgrall C., Hemingway J., Sharakhova M.V., Unger M.F., Collins F.H. \& Feyereisen R. 2002. Evolution of supergene families associated with insecticide resistance. Science. 298: $179-181$.

66 Renard G., Garcia J.F., Cardoso F.C., Richter M.F., Sakanari J.A., Ozaki L.S., Termignoni C. \& Masuda A. 2000. Cloning and functional expression of a Boophilus microplus cathepsin L-like enzyme. Insect Biochemistry and Molecular Biology. 30: 1017-1026.

67 Renard G., Lara F.A., Cardoso F.C., Miguens F.C., Dansa-Petretski M., Termignoni C. \& Masuda A. 2002. Expression and immunolocalization of a Boophilus microplus cathepsin L-like enzyme. Insect Molecular Biology. 11: 325-358.

68 Riding G.A., Jarmey J., Makenna R.V., Pearson R., Cobon G.S. \& Willadsen P. 1994. A protective “concealed” antigen from Boophilus microplus. Purification, localization, and possible function. Journal of Immunology. 153: 5158-5166.

69 Rosa de Lima M.F., Sanchez Ferreira C.A., Joaquim de Freitas D.R., Valenzuela J.G. \& Masuda A. 2002. Cloning and partial characterization of a Boophilus microplus (Acari: Ixodidae) glutathione S-transferase. Insect Biochemistry and Molecular Biology. 32: 747-754.

70 Rufingier C., Pasteur N., Lagnel J., Martin C. \& Navajas M. 1999. Mechanisms of insecticide resistance in the aphid Nasonovia ribisnigri (Mosley) (Homoptera: Aphididae) from France. Insect Biochemistry and Molecular Biology. 4: 385-391. 
71 Sabatini G.A., Kemp D.H., Hughes S., Nari A. \& Hansen J. 2001. Tests to determine LC50 and discriminating doses for macrocyclic lactones against the cattle tick, Boophilus microplus. Veterinary Parasitology. 95: 53-62.

72 Samish M. \& Glazer I. 2001. Entomopathogenic nematodes for the biocontrol of ticks. Trends in Parasitology. 17: 368-371.

73 Sanders M.L., Glass G.E., Nadelman R.B., Wormser G.P., Scott A.L., Raha S., Ritchie B.C., Jaworski D.C. \& Schwartz B.S. 1999. Antibody levels to recombinant tick calreticulin increase in humans after exposure to Ixodes scapularis (Say) and are correlated with tick engorgement indices. Americam Journal of Epidemiology. 149: 777-784.

74 Sanders M.L., Jaworski D.C., Sanchez J.L., DeFraites R.F., Glass G.E., ScottA.L. Raha, S. Ritchie B.C., Needham G.R. \& Schwartz. B.S. 1998. Antibody to a cDNA-derived calreticulin protein from Amblyomma americanum as a biomarker of tick exposure in humans. American Journal of Tropical Medicine and Hygiene. 59: 279-285.

75 Seixas A., Dos Santos P.C., Velloso F.F., Da Silva Vaz Jr., I., Masuda A., Horn F. \& Termignoni C. 2003. A Boophilus microplus vitellin-degrading cysteine endopeptidase. Parasitology. 126: 155-163.

76 Sorgine M.H., Logullo C., Zingali R.B., Paiva-Silva G.O., Juliano L. \& Oliveira P.L. 2000. A heme-binding aspartic proteinase from the eggs of the hard tick Boophilus microplus. Jounal of Biological Chemistry. 275: 28659-2865.

77 Sogorb M.A. \& Vilanova E. 2002. Enzymes involved in the detoxification of organophosphorus, carbamate and pyrethroid insecticides through hydrolysis. Toxicology Letters. 128: 215-228.

78 Sogorb M.A., Vilanova E., Quintanar J.L. \& Viniegra S. 1996. Bovine chromaffin cells in culture show carboxylesterase activities sensitive to organophosphorus compounds. International Journal of Biochemistry and Cell Biology. 9: 983-989.

79 Sutherst R.W., Jones R.J. \& Schnitzerling H.J. 1982. Tropical legumes of the genus Stylosanthes immobilize and kill cattle ticks. Nature 295: 320-321.

80 Sutherst R.W., Maywald G.F., Kerr J.D. \& Siegeman D.A. 1983. The effect of the cattle tick (Boophilus microplus) on the growth of Bos indicus x Bos taurus steers. Australian Journal of Agricultural Research. 34: 317-327.

81 Taylor M.A. 2001. Recent developments in ectoparasiticides. The Veterinary Journal. 161: 253-268.

82 Tellam R.L., Kemp D., Riding G., Briscoe S., Smith D., Sharp P., Irving D. \& Willadsen P. 2002. Reduced oviposition of Boophilus microplus feeding on sheep vaccinated with vitellin. Veterinary Parasitology. 103: 141-156.

83 Trimnell A.R., Hails R.S. \& Nuttall P.A. 2002. Dual action ectoparasite vaccine targeting 'exposed' and 'concealed' antigens. Vaccine. 20: 3560-3568.

84 Vonta, J.G., Small G.J., Nikou D.C., Ranson H. \& Hemingway J. 2002. Purification, molecular cloning and heterologous expression of a glutathione S-transferase involved in insecticide resistance from the rice brown planthopper, Nilaparvata lugens. Biochemistry Journal. 362: 329-337.

85 Wei S.H., Clark A.G. \& Syvanen M. 2001. Identification and cloning of a key insecticide-metabolizing glutathione S-transferase (MdGST-6A) from a hyper insecticide-resistant strain of the housefly Musca domestica. Insect Biochemistry and Molecular Biology. 31: 1145-1153.

86 Willadsen P., Cobon G. \& McKenna R.V. 1996. Comparative vaccination of cattle against Boophilus microplus with recombinant antigen Bm86 or in combination with recombinant Bm91. Parasite Immunology. 18: 241-246.

87 Young A.S. \& Morzaria S.P. 1986. Biology of Babesia. Parasitology Today. 2: 211-219.

88 Zhang C. \& Bennett G.N. 2005. Biodegradation of xenobiotics by anaerobic bacteria. Applied Microbiology and Biotechnology. 67: 600-618.

89 Zhioua E., Browning M., Johnson P.W., Ginsberg H.S. \& Lebrun R.A. 1997. Pathogenicity of the entomopathogenic fungus Metarhizium anisopliae (Deuteromycetes) to Ixodes scapularis (Acari: Ixodidae). Journal for Parasitology. 83: 815-818.

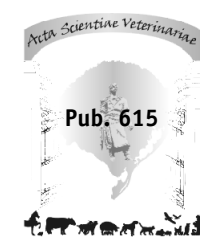




\title{
Eradication of Mycoplasma gallisepticum and M. synoviae from a chicken flock by antimicrobial injections in eggs and chicks
}

\author{
Erradicação de Mycoplasma gallisepticum e M. synoviae de um plantel \\ de galinhas pela injeção de antimicrobianos em ovos e pintos
}

\section{Elmiro Rosendo do Nascimento', Maria da Graça Fichel do Nascimento ${ }^{2}$, Maria Wanda dos Santos ${ }^{3}$, Paulo Genaro de Oliveira Dias ${ }^{4}$, Osvaldo de Almeida Resende ${ }^{4} \&$ Rita de Cássia Figueira Silva ${ }^{3}$}

\begin{abstract}
A chicken breeding flock of 3,464 hens, naturally infected with Mvcoplasma gallisepticum (MG) and M. svnoviae (MS), was subjected to a mycoplasma eradication scheme, based on antimicrobial treatment of eggs and their hatched dayold chicks. The egg injection sites utilized were the air cell and the small end (albumen), and the antibiotics used were tylosin at two different doses ( $3 \mathrm{mg}$ or $5 \mathrm{mg}$ per egg) and gentamicin $(0.6 \mathrm{mg} / \mathrm{egg})$. For the chicks treatment, a combination of spectinomycin and lincomycin, diluted in dextrose-vitamin complex solution, was employed. The differences in hatchability for the egg air cell-embryo (17.2\%), egg small end (albumen)-3mg tylosin (72.4\%) and egg small end (albumen)-5mg tylosin (42.1\%) injection procedures were significantly different by Chi-square analysis $(\mathrm{p}<0.0001)$. Injection of antimicrobials into the air cell resulted in the highest drop in hatchability, followed by tylosin dose of $5 \mathrm{mg}$ plus $0.6 \mathrm{mg}$ of gentamicin into the egg small end, compromising the further genetic use of their hatched chickens. The best performance on hatchability $(72.4 \%)$ was obtained when preincubated eggs were injected into the albumen with a combination of $3 \mathrm{mg}$ of tylosin plus $0.6 \mathrm{mg}$ of gentamicin. The difference in hatchability from $75.0 \%$ to $70.0 \%$ obtained, respectively, between lines A and B was not statistically significant. The $\mathrm{F} 1$ progenies from the antibiotic treated eggs stayed free from MG and MS until they reached the age of 12 months, when they were eliminated and replaced by their respective F2 substitutes.
\end{abstract}

Key words: chicken, Mycoplasma gallisepticum, M. synoviae, egg and embryo treatment, antimicrobial injection.

\section{RESUMO}

Um plantel de galinhas reprodutoras com 3.464 fêmeas, infectadas naturalmente por Mvcoplasma gallisepticum (MG) and M. svnoviae (MS), foi submetido a um processo de erradicação de micoplasma, com base no tratamento antimicrobiano de ovos e de seus respectivos pintos de um-dia de idade. Os sítios de injeção utilizados foram a câmara de ar e a ponta fina (albumina), sendo que os antimicrobianos usados foram tilosina em duas doses ( $3 \mathrm{mg}$ ou $5 \mathrm{mg}$ por ovo) e gentamicina $(0,6 \mathrm{mg} /$ ovo). Para o tratamento dos pintos, uma combinação de espectinomicina e lincomicina, diluidos numa solução dextrosecomplexo vitamínico, foi empregada. As diferenças em eclodibilidade para injeções na câmara de ar de cada ovo embrionado $(17,2 \%)$, na ponta fina do ovo (albumina)-3mg tilosina (72,4\%) e na ponta fina do ovo (albumina)-5mg tilosina (42,1\%) foram significativamente diferentes pelo teste de Qui-quadrado $(\mathrm{p}<0.0001)$. A injeção de antimicrobianos na câmara de ar resultou na mais elevada queda de eclosão, seguida pela dose de 5,0 $\mathrm{mg}$ de tilosina mais $0,6 \mathrm{mg}$ de gentamicina na ponta fina do ovo, comprometendo utilizações genéticas futuras das galinhas nascidas desses ovos. O melhor desempenho em eclodibilidade $(72,4 \%)$ foi obtido quando ovos pre-incubados foram injetados na ponta fina com uma combinação de 3,0 mg de tilosina mais 0,6 mg de gentamicina. A diferença em eclodibilidade de 75,0\% para 70,0\% obtida, respectivamente, entre as linhas A e B não foi estatisticamente significante. As progênies F1 dos ovos tratados com antimicrobianos permaneceram livres de MG e MS até a idade de 12 meses, quando foram eliminadas e substituídas por suas respectivas progênies F2.

Descritores: galinha, Mycoplasma gallisepticum, M. synoviae, egg and embryo treatment, antimicrobianos. 


\section{INTRODUCTION}

Mycoplasma gallisepticum (MG), responsible for chronic respiratory disease (CRD), and $M$. svnoviae (MS), that causes synovitis, are also the main cause of airsacculitis in poultry [6,13]. MG and MS infections can be transmitted horizontally (bird to bird), and vertically (through the egg), hence, affecting the breeding flocks [10]. The economic losses caused by mycoplasmosis are generally attributed to decreased laying performance, increased mortality and carcass condemnation rates, high medication cost, and synergistic effect associated with diseases or other factors $[3,6]$. Eradication of mycoplasma, based on its elimination into the egg, it is done without affecting the embryo development and subsequent hatchability of the mycoplasmafree progeny $[3,5,6,9,14]$. Informations on antimicrobial injection into the egg air cell, are found for chicken $[10,11]$, but with respect to egg small end (albumen) it is found for turkey hatching eggs [1,5]. Published studies on injection of chicken eggs to eliminate mycoplasma are scarse, because this procedure is mostly conducted within the commercial poultry premises [14]. Tylosin is very efficient against mycoplasmas, while spectinomycin, lincomycin and gentamicin are broadspectrum anti-microbials that work, preferably, against Enterobacteriaceae [8,9,15].

The objective of this study was to eradicate MG and MS from two chicken genetic stock lines, using procedures that included the injection of antibiotic into eggs, via small end and air cell, of MG and MS infected chicken, combined with antimicrobial treatment of day-old chicks, in order to provide an unbiased breeding selection, due to these mycoplasmas.

\section{MATERIALS AND METHODS}

\section{Chicken flock informations}

The chickens used were from a genetic stock of white-egg fowls (leghorn) ${ }^{1}$. When the egg treatment began, there were 3,464 hens in the flock, which were being used for genetic improvement research, with age ranging from 45 to 53 weeks old (average of 48 weeks), and a laying production ranging from $37.0 \%$ to $48.0 \%$ (average of $42.0 \%$ ). They were kept caged and artificially inseminated with semen from about 350 caged males. Out of these 3,462 hens, 1,929 constituted a sort of primary breeding flock (parent flock), which was divided into line "A" with
1,155 hens (father line) and line B with 774 (mother line). The others 1,535 hens were crosses between lines A and B, i.e., the multiplier breeding flock. These hens were housed in seven different groups, three of line $\mathrm{A}$, two of line $\mathrm{B}$, and two of $\mathrm{A} \times \mathrm{B}$ lines, of about 400 chickens, according to their exact ages. Prior to the beginning of this eradication scheme, all hens were tested for MG and MS infections by serum agglutination reaction (SAR $\}$ and hemagglutination inhibition (HI), as described [12]. Isolation of MG and MS in this flock was also accomplished [7,12], besides the history informations on the diagnosis of other disease [2].

\section{Drugs and their doses used}

For egg treatment, tylosin ${ }^{1}$ and gentamicin sulfate $^{2}$ were diluted in $85.0 \%$ saline. A volume of $0.1 \mathrm{~mL}$ of saline solution with $3.0 \mathrm{mg}$ or $5.0 \mathrm{mg}$ of tylosin and $0.6 \mathrm{mg}$ of gentamicin was inoculated per egg. Additionally, each day-old chick received a subcutaneous injection, containing $0.2 \mathrm{~mL}$ of a Linco-Spectin solution $^{3}$ (5.0 mg of lincomycin and $10 \mathrm{mg}$ of spectinomycin); $0.05 \mathrm{~mL}$ of $5.0 \%$ dextrose solution, and $0.05 \mathrm{~mL}$ of vitamin complex ${ }^{4}$.

\section{Injection procedures}

The eggs in trays were carefully inspected and dry-cleaned, whenever any dirt was seen on them. They were put air cell up or down, according to the chosen site of inoculation. The injection area of each egg, i.e., air cell or small end, were disinfected with iodine-alcohol solution applied gently with the help of a swab. Following desinfection, egg shell holes were made with a portable electric dentist drill ${ }^{5}$, attempting not to damage the shell membrane. The drills used were very small, and that made possible the abstention of holes of $0.5-0.8 \mathrm{~mm}$ in diameter. An automatic syringe ${ }^{6}$ of $1.0 \mathrm{~mL}$ with needle of $4 \mathrm{~mm} \times 5$ gauges in size was used to deliver the antimicrobial solution into the drilled eggs. Between injections, the needle was scoured in iodine-alcohol soaked gauze, being the gauze exchanged whenever drying was taking place. Albumen expressed during injection was wiped from the injection site with the help of gauze soaked in alcohol. After injection, the eggs holes were sealed with melted paraffin wax.

The automatic syringe as described above with needle of $5 \mathrm{~mm} \times 10$ gauges in size was used to inject a solution of antimicrobial and dextrose-vitamin, sub- 
cutaneously, in the dorsal region of the neck of each day-old chick.

\section{Egg handling and treatment procedures}

Eggs for each incubation/treatment batch were collected daily during a two-weeks interval. After each collection/day, the eggs were stored in a room with controlled temperature and humidity, where they received fumigation desinfection (formaldehyde gas) once or twice. Thereafter, the eggs were sent to the hatchery, located on the same premise, when they were fumigated again.

Eggs were treated and incubated in seven different batches, spaced about one week apart from each other. The numbers of eggs treated, the number of batches per line, the egg injection sites, and the combined doses of each antimicrobial used are presented under results (Table 1). The incubator and hatchery were cleaned thoroughly and disinfected before receiving the treated eggs. All eggs were fumigated at the entrance of the incubation room, after anti-microbial treatment, and when transferred to the hatchery. Incubated eggs in trays were removed from the incubation place, treated with antimicrobials, fumigated and immediately returned to their previous location. Eggs subjected to preincubation treatment, i.e., the albumen injected ones, were incubated about two hours after finishing the injection procedure. The eggs were subjected to candling prior to incubation, and every four days from 4-17 post-incubation days, for the elimination of un-fertile eggs and/or dead embryos.

\section{Management of the Fl Progenies}

Not all hatched chicks were used for subsequent breeding purpose. All saved chicks were subjected to sexing and most of the males were culled. The selected chicks were put in a chicken house located about 1,000 meters away from their mother hens, where they stayed until about 100 days, being, then, caged. By this time, their parents had already been culled, slaughtered and marketed a month before. The $\mathrm{Fl}$ progenies were placed in houses and cages that had been cleaned, disinfected, and emptied for at least a month before use. Biosecurity measures, which included control of personnel, ration, vehicles, fomites, etc. were adopted.

\section{Monitoring scheme}

All pipped embryos from treated eggs were bled, sacrificed, necropsied and inspected for air sac lesions. All embryos with lesions, and only five without, from each incubation batch were subjected to culturing for mycoplasma isolation $[7,12]$. The sera obtained from the pipped embryos were pooled in groups of five and subjected to SAR and HI for MG and MS. SAR was

Table 1. Egg Parameters by Injection site and Treatment Procedure ( $0.6 \mathrm{mg}$ of gentamicin plus tylosin at $3 \mathrm{mg}$ or $5 \mathrm{mg})$.

\begin{tabular}{lcccr} 
& \multicolumn{3}{c}{ Egg treatment procedure } & \multirow{2}{*}{$\begin{array}{c}\text { Total eggs } \\
\text { used }\end{array}$} \\
\cline { 2 - 4 } Egg parameters & $\begin{array}{c}\text { Air cell } \\
\text { Tylosin 3mg }\end{array}$ & $\begin{array}{c}\text { Albumen } \\
\text { Tylosin } 3 \mathrm{mg}\end{array}$ & $\begin{array}{c}\text { Albumen } \\
\text { Tylosin } 5 \mathrm{mg}\end{array}$ & 15,585 \\
\hline Layed & 789 & 6,792 & 8,004 & 14,220 \\
Fertiles & 517 & 6,127 & 7,576 & 7,719 \\
Hatched & 89 & 4,436 & 3,194 & $91.2 \%$ \\
Fertility & $65.5 \%$ & $90.2 \%$ & $94.6 \%$ & $314(4.0 \%)$ \\
Pipped, \# and (\%) & $7(8.0 \%)$ & $127(2.9 \%)$ & $180(5.6 \%)$ & $54.3 \%$ \\
\hline Hatchability & $17.2 \%$ & $72.4 \%$ & $42.1 \%$ & \\
\hline
\end{tabular}

1. One incubation with embryos, treated on the $8^{\text {th }}$ incubation day, from line A hens.

2. Two incubations for line A eggs and two others for line B.

3. Two incubations with eggs from lines $\mathrm{A} \times \mathrm{B}$ hens.

4. Chi-square analysis, not significant $(\mathrm{p}=0.132)$

5. Chi-square analysis, $(P<0.0001)$. 
performed with commercial antigens for $\mathrm{MG}^{7}$ and $\mathrm{MS}^{7}$ and the HI was conducted with laboratory made antigen ${ }^{9}$, with four hemagglutinating units, according to standard procedures $[6,12]$.

The F1 progenies were monitored for MG and MS infections by serology (SAR and HI) and culturing. Culturing was performed on specimens from birds that appeared dead, sick, and from those apparently healthy, by the tracheal swab procedure [12]. Serology was performed when the chickens $(100 \%$ of them) were aging 2-3 months, 5-6 months and 1112 months (replacement time).

\section{Statistical analysis}

Chi Square test for heterogeneity with confidence interval of $95 \%$ [4] was used to compare the proportions of hatched, pipped and unhatchad eggs from the three treatment groups under trial, as well as to investigate the genetic effect on hatchability, using eggs injected in the small end, and under the same antimicrobial dose ( $3 \mathrm{mg}$ of tylosin plus $0.6 \mathrm{mg}$ of gentamicin), from lines A and B.

\section{RESULTS}

Of the 3,464 hens tested prior to the beginning of the egg treatment, 3,118 (90.0\%) and 2,078 (60.0\%) were, respectively, positive for MG and MS by SAR and HI. These and other untyped mycoplas- monellosis. Non-bacterial diseases had also been diagnosed as coccidiosis, aspergillosis, Marek's disease, Lymphoyd leukosis, Newcastle disease, and Infectious Bursal Disease.

A total of 15,584 eggs with fertility rates ranging from $65.5 \%$ to $94.6 \%$ were subjected to antimicrobial treatment, and data pertaining to fertility, and hatching performance per treatment scheme (injection site and dose of tylosin) is being presented (Table 1). The hatchability for the air cell treated embryos (8days of incubation) was drastically smaller $\left(\chi^{2}\right.$ analyzes, $\mathrm{p}<0.0001)$ than that obtained for the small end, i.e., albumen site of preincubated eggs (Table 1). Increasing the tylosin dose from $3 \mathrm{mg}$ to $5 \mathrm{mg}$ reduced the hatchability from $72.4 \%$ to $42.1 \%$, difference also statistically significant $(\mathrm{p}<0.0001)$ by $\chi^{2}$ analyzes (Table 1$)$. The treatment scheme used, had no effect on pipped embryo frequency (Table 1).

The effect of the antimicrobial treatment, by the albumen route, on chickens from the lines $\mathrm{A}$ and $\mathrm{B}$ was investigated by $\chi^{2}$ analyzes, but there was no statistical differences (table 2), although the hatchabilities obtained was $75.0 \%$ for line A, and $70.0 \%$ for line B (Table 2).

\section{DISCUSSION}

The antimicrobial egg treatment scheme described herein, which included the treatment of day-

Table 2. Effect of egg treatment ( $3.0 \mathrm{mg}$ of tylosin plus $0.6 \mathrm{mg}$ of gentamicin) on two chicken lines ${ }^{1}$

\begin{tabular}{|c|c|c|c|c|c|c|}
\hline & & \multicolumn{5}{|c|}{ Egg parameters, number and (\%) } \\
\hline \multicolumn{2}{|c|}{ Line Incubated } & Fertiles & Hatched & Pipped & Fertility & Hatchability $^{2}$ \\
\hline A & 3,457 & 2,998 & 2,247 & 66 & $(87.0)$ & $(75.0)$ \\
\hline B & 3,515 & 3,129 & 2,189 & 61 & (89.0) & (70.0) \\
\hline
\end{tabular}
old chicks and biosecurity measures, was sufficient for the obtention of MG and MS-free chickens with only one application.

Tylosin was used because of its proven efficiency against mycoplasmas $[8,15]$ and gen-

mas had been isolated from necropsied birds from this flock several times in the past, prior to this eradication trial. The diagnosis of Chronic Respiratory Disease (CRD) and/or Airsacculitis with and without the possible involvement of Escherichia coli was also obtained in necropsied chickens, culled prior to this antimicrobial treatment trial.

As to the records of other diseases that were diagnosed in previous years, informations were available on other bacterial diseases, such as Infectious Coryza (Haemophilus parallinarum) and non-pullorum sal- tamicin was used because of its broad-spectrum activity against bacteria and its low toxicity to host cells [15]. The use of gentamicin was justified also by the information on bacterial diseases, including non-pullorum salmonellosis, diagnosed in this genetic flock in previous years. Tylosin can be toxic for eggs when used in high doses as evidenced by the drop in hatchability, observed when the dose of this antibiotic was increased from $3 \mathrm{mg}$ to $5 \mathrm{mg} / \mathrm{egg}$.

The positive reactions obtained for sera from pipped embryos on the HI test can be explained by the 
presence of maternal antibodies transmitted from hens to their eggs. The use of uninoculated eggs to serve as a control group was not employed due to the risk of compromising the eradication scheme adopted. The variation in fertility rates observed on different incubation batches of eggs may be explained by the way these hens were fertilized, i.e., by artificial insemination.

The better hatchability results obtained for eggs treated in the small end (albumen) over the air cell route has also been observed in the case of turkey eggs [5]. Because of the drastic mortality of embryos treated by the air cell route, this procedure was discontinued and the chicks hatched were not saved for breeding purposes. Besides, chicks hatched from eggs treated with $5 \mathrm{mg}$ of tylosin, due also to high mortality, were not saved for breeding purposes, due to the fear of loosing genetic variability, hence, compromising future crossings.

The antimicrobial treatment of eggs alone should not be judged responsible for the success of this eradication scheme, as day-old chick antibiotic treatment, biosecurity, and flock monitoring were also adopted. With the eradication of MG and MS, the genetic selection and breeding improvement can be carried out in this chicken genetic stock without the nega- tive effects caused by the presence of MG and MS infections.

\section{CONCLUSION}

Antimicrobial treatment of preincubated eggs at the small end (albumen), in conjunction with treatment day-old chicks hatched from treated eggs, was sufficient to eliminate MG and MS from a genetic chicken stock flock with only one application.

\section{SOURCES AND MANUFACTURERS}

${ }^{1}$ Experimental Station of Rio de Janeiro State Research Agricultural Organization-PESAGRO/RIO, Itaguai, RJ, Brazil.

${ }^{2}$ Tylosin - "Tylan Soluvel, Elanco Quimica LTDA/Eli Lilly do Brasil LTDA, São Paulo, SP, Brasil".

${ }^{3}$ Gentamicin Sulfate - Gentocin ,"Industria Química e Farmacêutica Schering S/A, Rio de Janeiro, RJ, Brasil".

${ }^{4}$ Linco-Spectin solution - TUCO, "Divisão de Upjohn Produtos Farmacêuticos LTDA, São Paulo, SP, Brasil”.

${ }^{5}$ Vitamin Complex - "Poli Vitaminico SM-Forte, Laboratório Santa Marina", Brasil".

${ }^{6}$ Electric dentist drill - Dentalwerk Burmoos, GES. M.B.H., Salzburg, Austria.

${ }^{7}$ Automatic syringe - FHK PISTOR 1-FJ-96, Fujihira Industry Co. Inc., Japan.

${ }^{8}$ Commercial antigens for MG and MS - BIOVET S/A, Vargem Grande Paulista, SP, Brazil.

${ }^{9}$ Projeto Saúde Animal (PSA)/Embrapa Agrobiologia, Seropédica, RJ, Brazil.

\section{REFERENCES}

1 Ghazikhanian G., Yamamoto R., McCapes H., Dungan W.M. \& Ortmayer H.B. 1980. Combination dip and injection of turkey eggs with antibiotic to eliminate Mycoplasma meleagridis infection from a primary breeding stock. Avian Diseases. 24: 57-70.

2 Hitchner S.B., Domermuth C.H., Purchase C.G. \& Williams J.E. 1980. Isolation and Identification of Avian Pathogens. 2nd edn. New York: Creative Printing Company Inc. Endwell, 155p.

3 Lay D.H. \& Yoder Jr. H.W. 1997. Mycoplasma gallisepticum infection. In: Calnek B.W., Barnes H., Beard C.W., Mcdougald L.R. \& SaifY.M. (Eds). Diseases of Poultry. Ames: Iowa State University Press, pp.194-207.

4 Martin S. W., Meek A. H. \& Willeberg P. 1994. Veterinary Epidemiology: Principles and Methods. Ames: Iowa State University Press, pp.121-148..

5 McCapes R.H., Yamamoto R., Ghazikhanian G., Dungan W.M. \& Ortmayer H.B. 1977. Antibiotic egg injection to eliminate disease. I. Effect of injection methods on turkey hatchability and Mycoplasma meleagridis infection. Avian Diseases. 19: $57-68$.

6 Nascimento E.R. 2000. Mycoplasmoses. In: Macari M.\& Berchieri Jr. A. (Eds). Doenças das Aves. Campinas: FACTA, pp. 217-240.

7 Nascimento M.G.F. \& Nascimento E. R. 1986. Infectious sinusitis in coturnix quails in Brazil. Avian Diseases. 30: $228-230$.

8 Prescott J.F. 1990. Antimicrobial Chemotherapy. In: Biberstein E.L. \& Zee Y.C. Review of Veterinary Microbiology. Chicago: Blackwell Scientific Publications, pp.56-90.

9 Stipkovits L. \& Kempf I. 1996. Mycoplasmoses in poultry. Revue Scientifique et Technique de l'Office Internationale des Épizooties. 15: 1495-1525.

10 Truscott R.B. \& Fergusson A.E. 1975. Studies on the control of Mycoplasma gallisepticum in hatching eggs. Canadian Journal of Comparative Medicine. 39: 235-239. 
11 Tudor D.C. \& Woodward H. 1968. A mass method for chicken embryo inoculation with tylosin. Avian Diseases. 12: $379-382$.

12 USA. 1997. United States Department of Agriculture. National Poultry and Improvement Plan and Auxiliary Provisions. Washington, DC: USDA, 98p.

13 Yoder Jr. H.W. 1991. Avian mycoplasmosis. In: Calnek B.W., Barnes H.J., Beard C.W., Reid W. M. \& Yoder Jr. H.W. (Eds). Diseases of Poultry. 9th edn. Ames: Iowa State University Press, pp.197-198.

14 Yoder Jr. H.W. 1991. Mycoplasma gallisepticum infection. In: Calnek B.W., Barnes H.J., Beard C.W., Reid W.M., \& Yoder Jr. H.W. (Eds). Diseases of Poultry. 9th edn. Ames: Iowa State University Press, pp.198-212.

15 Youmans G.R., Patterson P.Y. \& Sommers H.M. 1985. The biological and clinical basis of infectious diseases. 3rd edn. Philadelphia: Saunders Co, pp.814-815. 